\title{
PENGARUH PENAMBAHAN EKSTRAK JAHE (Zingiber Officinale) SEBAGAI ANTIOKSIDAN PADA EDIBLE FILM PATI GANYONG (Canna edulis) DAN LIDAH BUAYA (Aloe vera .L) TERHADAP MASA SIMPAN BUAH TOMAT (Lycopersicum esculentum)
}

\author{
Anggi Sulistyowati ${ }^{1}$, Endaruji Sedyadi ${ }^{*}$, Susy Yunita Prabawati ${ }^{1}$ \\ ${ }^{1}$ Program Studi Kimia, Fakultas Sains dan Teknologi \\ Universitas Islam Negeri Sunan Kalijaga Yogyakarta \\ Jalan Marsda Adisucipto Yogyakarta 55281 \\ endaruji@yahoo.com
}

Artikel Info
$\begin{aligned} & \text { Diterima } \\ & \text { tanggal }\end{aligned}$
12.12 .2018
Disetujui
publikasi
tanggal
30.04 .2019
Kata kunci :
Edible film,
ekstrak kunyit,
gliserol, pati
ganyong, sifat
mekanik
film tanpa ekstrak jahe menjadi 48 hari, dan tomat yang dilapisi edible film dengan penambahan ekstrak jahe dapat yaitu 65 hari. Penurunan tingkat kekerasan tekstur sebesar 63\% pada tomat yaitu 7 hari menjadi 7,5 hari dengan pelapisan edible film tanpa ekstrak jahe, sedangkan dengan pelapisan edible film dengan penambahan ekstrak jahe menjadi 12 hari

\section{ABSTRACT}

Research about the preparations of edible films made from canna tuber, aloe vera, glycerol and ginger extract has been done. Research was carried out in order to determine the effect of ginger extract on the edible film of canna-aloe vera starch on mechanical properties, WVTR, and its application to extend the shelf life of fruit This research was conducted in several stages. There were making ginger extract, making edible canna-aloe vera starch film, making edible film of aloe vera tuber with the addition of ginger extract, testing the mechanical properties of edible film, WVTR, and application of edible film to fruit tomato. Based on the research that has been done, edible aloe vera starch film has a tensile strength of $11.89 \mathrm{MPa}$, elongation of $12.71 \%$, and WVTR of $7.45 \mathrm{~g} / \mathrm{m} 2$.hour. The optimal result of edible film with the addition of ginger extract is the addition of $0.75 \%$ (b/b) of ginger extract, namely the tensile strength of $5.17 \mathrm{MPa}$, elongation of $9.74 \%$ and WVTR value of $8.92 \mathrm{~g} / \mathrm{m} 2$. hour. The addition of ginger extract into edible film

doi: http://dx.doi.org/10.23960/aec.v4.i1.2019.p01-12

Anal.Environ.Chem.Anal.Environ.Chem. 
was able to maintain the quality and shelf life of tomatoes when viewed based on $50 \%$ shrinkage weight and $63 \%$ damage to texture. Depreciation of $50 \%$ of tomato weight without coating edible film is 45 days, then tomatoes with edible film coating without ginger extract become 48 days, and tomatoes coated with edible film with the addition of ginger extract can be 65 days. Decrease in the level of texture hardness by $63 \%$ in tomatoes which is 7 days to 7.5 days by coating edible film without ginger extract, while by coating edible film with the addition of ginger extract to 12 days.

\section{PENDAHULUAN}

Tomat merupakan salah satu jenis buah yang sangat digemari masyarakat. Tomat memiliki banyak kandungan gizi yang baik bagi kesehatan tubuh. Kandungan gizi pada buah tomat yang banyak diketahui adalah vitamin $\mathrm{C}$ dan mineral yang cukup tinggi. Tomat memiliki banyak kandungan air, sehingga renta terhadap kerusakan dan pembusukan. Beberapa faktor yang dapat mempengaruhi pembusukan tomat adalah faktor fisiologis dan mikrobiologis. Kedua faktor tersebut sangat mempengaruhi kualitas dari tomat. Gejalanya dapat ditunjukkan dengan adanya penurunan kualitas tomat seperti perubahan bentuk fisik menjadi lebih lembek dan tekstur yang tampak keriput.

Salah satu alternatif yang dapat dipilih untuk memperpanjang masa simpan tomat adalah pengemasan dengan menggunakan edible film. Edible film merupakan lapisan tipis yang terbuat dari bahan yang aman untuk dikonsumsi sebagai lapisan penghalang untuk meningkatkan kualitas dan masa simpan suatu produk makanan. Fungsi pelindung edible film adalah untuk mencegah proses oksidasi, penyerapan dan desorpsi kelembapan, kontaminasi, pertumbuhan mikroba dan perubahan sensorik (Pavlath and Orts, 2009).

Salah satu bahan dasar pembuatan edible film yaitu pati. Pati memiliki kandungan amilosa yang mampu membentuk lapisan tipis dengan ikatan yang kuat sehingga dapat membentuk edible film yang baik (Krochta dan Johnson, 1997). Pati ganyong merupakan salah satu sumber pati yang memiliki kandungan amilosa, sehingga berpotensi besar sebagai bahan baku edible film. Sifatnya yang dapat membentuk gelatin menjadikan bahan ini mudah diaplikasikan sebagai pembentuk dan dapat menghasilkan film yang baik. Gel lidah buaya ditambahkan sebagai kombinasi pati ganyong untuk memperoleh karakteristik sifat edible film yang bermutu tinggi.

Edible film selian berfungsi sebagai pelapis makanan, dapat juga dimanfaatkan sebagai active packaging atau sebagai pembawa komponen aktif seperti antioksidan dan antimikroba (Robertson, 1992). Penambahan komponen aktif pada edible film dapat menambah nilai fungsi 
edible film.Jahe dapat dimanfaatkan sebagai salah satu sumber antioksidan alami karena kaya akan senyawa fenolik yang merupakan senyawa aktif antioksidan (Zakaria et al, 2000). Salah satu cara untuk mendapatkan senyawa yang terdapat jahe berupa ekstrak adalah dengan melakukan ekstraksi. Penambahan ekstrak jahe pada edible film pati ganyong dan lidah buaya akan memberikan pengaruh terhadap sifat mekanik edible film dan kualitas tomat selama masa simpan akibat kandungan antioksidan yang akan meningkatkan kemampuan edible film untuk menghambat laju respirasi dati buah tomat.

\section{METODE}

\section{Alat dan Bahan}

Alat yang digunakan yaitu hot plate, oven, evaporator, blender, gelas beker, plastik mika, magnetic stirer, dan termometer. Bahan utama yang digunakan untuk penelitian ini adalah pati ganyong (Canna edulis Ker.), lidah buaya (Aloe vera L.), gliserol, jahe, etanol 96\%, dan akuades.

\section{Prosedur}

\section{Pembuatan Ekstrak Jahe}

Rimpang jahe dikupas dan diiris tipis kemudian dikeringkan dalam oven pada suhu $60^{\circ} \mathrm{C}$ selama 6 jam. Jahe yang telah kering dihaluskan dengan blender. Sebanyak 25 gram serbuk jahe dilarutkan dalam etanol 96\% dengan perbandingan 1:5 dan dipanaskan selama 120 menit pada suhu $40^{\circ}$ dengan pengadukan. Larutan didiamkan selama 24 jam kemudian disaring untuk memisahkan antara filtrat dengan serbuk jahe yang mengendap. Filtrat ekstrak jahe kemudian dikentalkan dengan menggunakan vacum rotary evaporator (Saragih et al, 2015). Kemudian dilakukan uji FTIR dan Aktivitas Antioksidan

\section{Pembuatan Edible Film}

Lidah buaya dan pati ganyong ditimbang dengan proporsi masing-masing 3\% dan $6 \%$ kemudian gliserol ditimbang 15\% (b/btotal) dari berat campuran gel lidah buaya dan pati ganyong yang ditambahaan dan dibuat suspensi dengan penambahan akuades hingga 100ml. Kemudian dilakukan pemanasan pada suhu $70^{\circ} \mathrm{C} \pm 5^{\circ} \mathrm{C}$ selama 30 menit dan pengadukan menggunakan magnetic stirer (Afriyah et al, 2015). Suspensi didinginkan hingga suhu $50^{\circ} \mathrm{C}$ dalam keadaan tetap diaduk kemudian ditambahkan ekstrak jahe dengan konsentasi yang divariasikan 0\%; 0,5\%; $0,75 \%, 1 \%$. selanjutnya dilakukan penuangan sebanyak $25 \mathrm{ml}$ ke plastik mika ukuran $13 \times 18 \mathrm{~cm}$ kemudian dikeringkan. Kemudian dilakukan uji sifat fisik dan FTIR. 


\section{Aplikasi Edible Film terhadap Buah Tomat}

Aplikasi edible film terhadap buah tomat dengan menggunakan metode pembungkusan. Buah tomat sebelum diaplikasikan dengan edible film, dibersihkan terlebih dahulu kemudian dibungkus rapat menggunakan edible film dengan penambahan ekstrak jahe $0 \%$ dan $0,75 \%$. Daya simpan buah tomat diamati dengan melakukan uji susut bobot pada hari ke- $0,1,2,3,6$, dan 7 sedangkan uji testur dilakukan pada hari ke-1 dan ke-7. Hasil yang didapatkan dibandingkan dengan buah tomat yang tidak dibungkus dengan edible film (kontrol).

\section{HASIL DAN PEMBAHASAN}

\section{Ekstraksi Jahe}

Metode yang digunakan untuk mendapatkan ekstrak jahe yaitu metode digesti. Metode digesti adalah metode yang dilakukan dengan cara melarutkan bahan yang akan diekstraksi pada suatu pelarut dengan perbandingan tertentu dan dilakukan pengadukan (Lestari, 2006). Ekstrak yang dihasilkan berwarna cokelat pekat kehitaman berupa pasta kental. Rendemen yang diperolehyaitu sebesar $8,56 \%$.

Ekstrak jahe dianalisis menggunakan spektrofotometer FT-IR untuk mengetahui gugus fungsi yang terdapat didalamnya dan diidentifikasi pada bilangan gelombang $4000-400 \mathrm{~cm}^{-1}$. Spektrum FT-IR hasil analisis ekstrak jahe ditunjukkan pada gambar berikut.

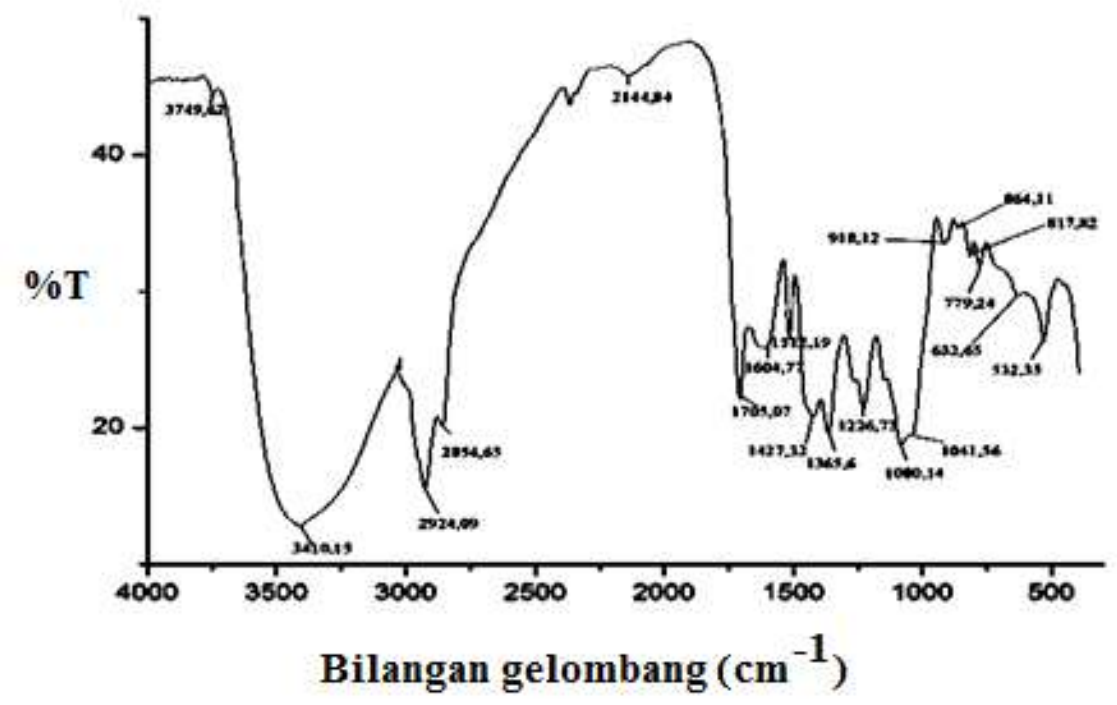

Gambar 1. Spektra FTIR ekstrak jahe 
Serapan khas yang muncul pada spektrum FTIR diatas yaitu pada bilangan gelombang $3410,15 \mathrm{~cm}^{-1} ; 1705,07 \mathrm{~cm}^{-1} ; 1604,77 \mathrm{~cm}^{-1}$; dan $1226,73 \mathrm{~cm}^{-1}$ masing-masing bilangan gelombang tersebut menunjukkan adanya serapan gugus $\mathrm{OH}, \mathrm{C}=\mathrm{O}, \mathrm{C}=\mathrm{C}$ aromatik, dan $\mathrm{C}-\mathrm{O}$. Gugus tersebut dapat dikatakan serapan khas dari senyawa gingerol atau shogaol yang terapat pada ekstrak jahe sebagai senyawa antioksidan.

Ekstrak jahe kemudian diuji aktivitas antioksidan. Hasil yang diperoleh berupa nilai $\mathrm{IC}_{50}$ yaitu sebesar 92,53 ppm. Hasil tersebut menunjukkan bahwa antioksidan pada ekstrak jahe memiliki nilai aktivitas antioksidan yang cukup kuat.nilai aktivitas antioksidan yang dianggap kuat yaitu kurang dari 200 ppm (Blouis, 1958)

\section{Karakteristik Edible Film Pati Ganyong-Lidah Buaya}

Karaktersitik edible film pati ganyong-lidah buaya yang diperoleh dari uji sifat fisik yang dilakukan yaitu ketebalan 0,0325 mm, kuat tarik 11,89 MPa, elongasi 12,71 \%, Modulus Young 0,935 MPa, dan WVTR sebesar 7,45 g/m² jam (Gambar 2 dan Gambar 3). Hasil tersebut jika dibandingkan dengan Japan Industrial Standart pada Tabel 1, menunjukkan bahwa edible film yang dihasilkan secara karakteristik memenuhi standar sebagai edible film.

Tabel 1. Standar Edible Film Menurut Japan Industrial Standart (1975)

\begin{tabular}{lc}
\hline \multicolumn{1}{c}{ Karakteristik } & Nilai \\
\hline Ketebalan $(\mathrm{mm})$ & $<0,25$ \\
Kuat Tarik $(\mathrm{Mpa})$ & $>3,92266$ \\
Elongasi $(\%)$ & Buruk $<10$ \\
& Baik $>50$ \\
Modulus Young $(\mathrm{Mpa})$ & $>0,35$ \\
WVTR $\left(\mathrm{g} / \mathrm{m}^{2}\right.$.jam $)$ & $<10$ \\
\hline
\end{tabular}

\section{Karakteristik Edible Film dengan Penambahan Ekstrak Jahe}

Hasil pengukuran laju transmisi uap air selaras dengan hasil uji sifat mekanik pada konsentrasi penambahan ekstrak jahe sebanyak 0,75\% yang memiliki nilai karakteristik optimum. Pada konsentrasi penambahan ekstrak jahe 0,75\% komponen pembentuk edible film tercampur 
homogen sehingga mampu berinteraksi dengan baik dan berikatan membentuk matriks film yang lebih kuat. Edible film dengan penambahan ekstrak jahe 0\% dan 0,75\% kemudian diuji FTIR untuk mengetahui sifat kimia yang terdapat pada edible film (Sedyadi, 2016). Spektrum FTIR edible film 0\% dan $0,75 \%$ ditunjukkan pada Gambar 4 .
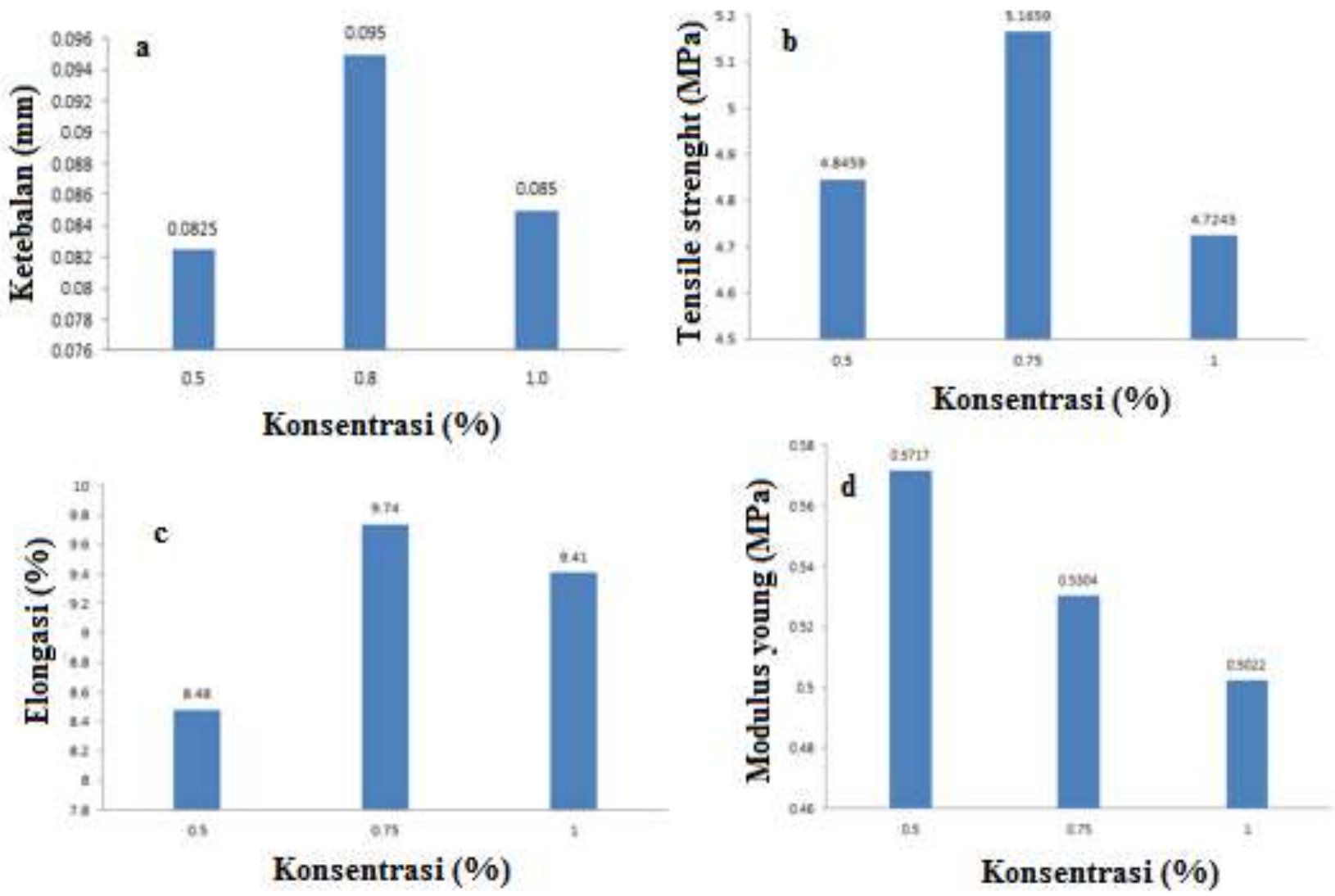

Gambar 2. Hasil Uji Ketebalan (a), uji kuat Tarik (b), uji elongasi (c), dan uji Modulus Young (d) 


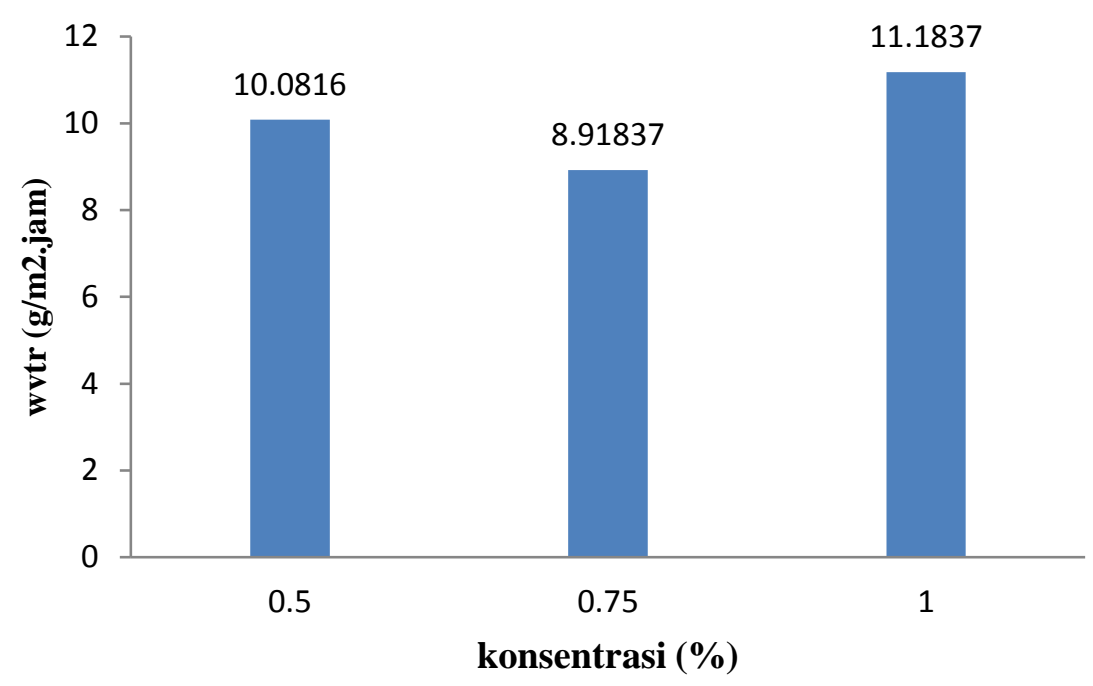

Gambar 3. Hasil Uji WVTR

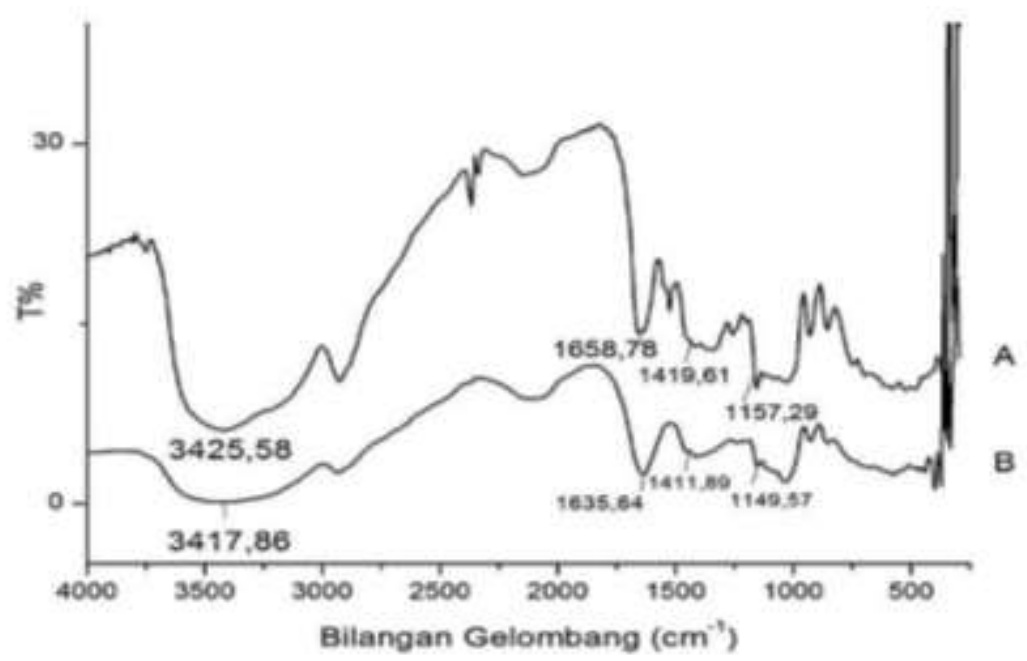

Gambar 4. Edible Film tanpa penambahan ekstrak jahe (a) dan Edible film dengan penambahan ekstrak jahe (b)

Edible film dengan penambahan ekstrak jahe terjadi pelebaran puncak pada bilangan gelombang $3417,86 \mathrm{~cm}^{-1}$ yang menunjukkan adanya gugus $\mathrm{OH}$, sedangkan edible film tanpa ekstrak ditunjukkan pada bilangan gelombang $3425,58 \mathrm{~cm}^{-1}$. Pada gugus $\mathrm{OH}$ tersebut terjadi pergeseran intensitas yang disebabkan adanya pertambahan gugus $\mathrm{OH}$ yang berasal dari senyawa fenolik yang berasal dari ekstrak jahe. Pergesaran bilangan gelombang $1658 \mathrm{~cm}^{-1}$ menjadi 1635,64 $\mathrm{cm}^{-1}$ menunjukkan adanya gugus stretching $\mathrm{C}=\mathrm{O}$ dan pergeseran pada bilangan gelombang $1157,29 \mathrm{~cm}^{-1}$ menjadi $1149,57 \mathrm{~cm}^{-1}$ sebagai pergeseran serapan gugus $\mathrm{C}-\mathrm{O}$ stretching. Pergeseran 
bilangan gelombang tersebut menunjukkan adanya interaksi cenderung secara fisik dibandingkan secara kimia karena tidak adanya serapan baru yang muncul pada edible film dengan penambahan ekstrak jahe. Serapan baru muncul ketika terjadi interaksi secara kimia. Interaksi fisik yang terjadi yaitu disebabkan adanya interaksi pada ikatan hidrogen pada polimerisasi penyusun edible film. Interaksi tersebut yang mempengaruhi perbedaan sifat mekanik antara edible film tanpa penambahan ekstrak jahe dan penambahan ekstrak jahe

\section{Aplikasi Edible Film terhadap Buah Tomat}

\section{Uji Susut Bobot}

Susut bobot merupakan keadaan yang disebabkan karena terjadinya respirasi dan transpirasi buah pasca panen sebagai proses biologis dimana oksigen diserap untuk membakar bahan-bahan organik dalam buah untuk menghasilkan energi yang diikuti oleh pengeluaran sisa pembakaran berupa gas karbondioksida dan air yang mengalami penguapan (Alexandra dan Nurlina, 2014). Reaksi respirasi yang menyebabkan peningkatan susut bobot sebagai berikut :

$\mathrm{C}_{6} \mathrm{H}_{12} \mathrm{O}_{6}+6 \mathrm{O}_{2} \rightarrow 6 \mathrm{CO}_{2}+6 \mathrm{H}_{2} \mathrm{O}+$ Energi (Ekawati, 2015). Akibat berkurangnya kandungan air pada buah karena adanya proses transpirasi tersebut yang akan menyebabkan buah mengalami penyusutan. Hasil pengukuran susut bobot tomat disajikan pada Gambar 5.

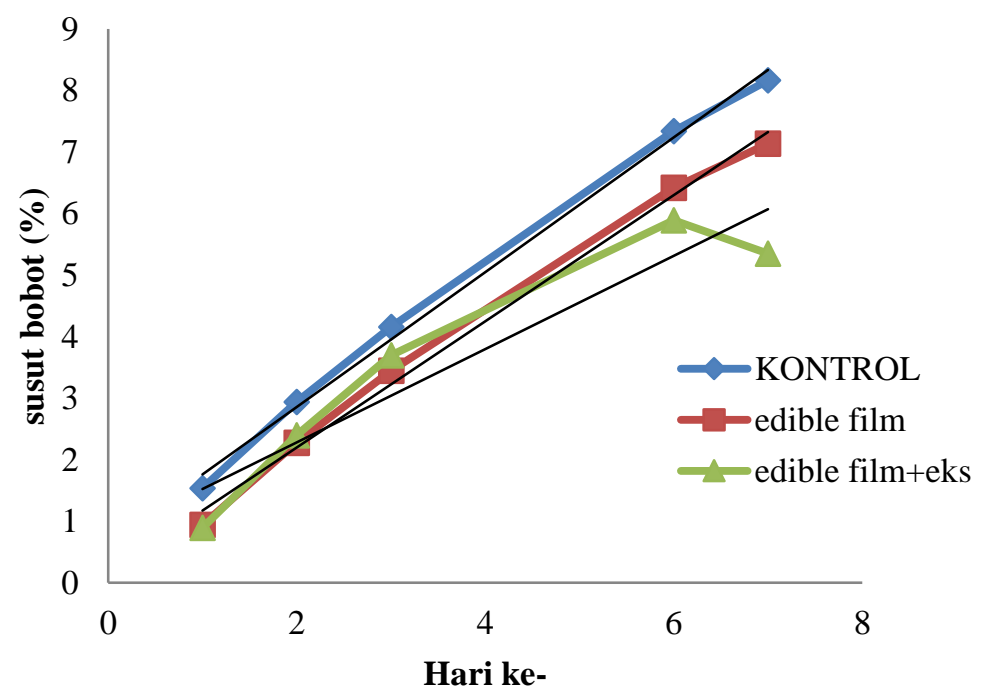

Gambar 5. Hasil Uji Susut Bobot Buah Tomat 
Susut bobot yang dialami tomat tanpa pelapisan edible film sebesar 1,54-8,16\% lebih besar dibandingkan dengansusut tomat yang dilapisi edible film tanpa penambahan ekstrak jahe dengan presentase sebesar $0,94-7,14 \%$ dan susut bobot tomat yang dilapisi dengan edible film penambahan ekstrak jahe konsentrasi 0,75\% yaitu sebesar 0,89-5,39\%.

Edible film dengan penambahan ekstrak jahe konsentrasi $0,75 \%$ cenderung menunjukkan nilai susut bobot yang lebih rendah dibandingkan dengan edible film tanpa penambahan ekstrak. Penambahan ektrak jahe pada edible film pati ganyong-lidah buaya meningkatkan nilai fungsional edible film dengan membawa kompenen aktif antioksidan yang mampu berperan sebagai antioksidasi untuk menghambat adanya kontak oksigen dengan tomat yang memicu laju respirasi yang menyebabkan kerusakan dari buah tomat. Menurut Krochta et al (1994), pelapisan menggunakan edible film berbahan dasar polisakarida memiliki kemampuan untuk menghambat kematangan berbagai buah yang bersifat klimaterik dan mampu meningkatkan umur simpan tanpa menghasilkan suasana anaerobik yang tinggi.

Kemampuan edible film dalam memperpanjang masa simpan tomat berdasarkan susut bobot dapat dilihat dengan susut bobot yang hilang hingga 50\% pada tomat. Pada tomat tanpa pelapisan edible film (kontrol) akan kehilangan susut bobot 50\% pada hari ke-45, kemudian pada tomat dengan pelapisan edible film tanpa penambahan ekstrak jahe akan kehilangan susut bobot 50\% yaitu pada hari ke-48, sedangkan tomat dengan pelapisan edible film dengan penambahan ekstrak jahe memiliki waktu yang lebih lama dibandingkan tomat kontrol dan tomat pelapisan edible film tanpa penambahan ekstrak yaitu pada hari ke-64. Perbedaan hari yang sangat besar tersebut menunjukkan edible film dengan penambahan ekstrak jahe memberikan pengaruh nyata dalam memperpanjang masa simpan tomat dengan menghambat susut bobot tomat.

\section{Uji Tekstur}

Tekstur adalah salah satu uji yang berkaitan dengan kekerasan buah. Semakin lama penyimpanan, buah akan mengalami penurunan kekerasan atau semakin lunak. Pelunakan buah dipengaruhi oleh adanya proses respirasi dan transpirasi pada buah. Respirasi yang terjadi pada buah pascapanen akan menyebabkan adanya proses perombakan polisakarida dan penyusun dinding sel. Buah akan semakin lunak seiring dengan semakin besar perombakan polisakarida (Purwadi et al, 2007). Menurut Ahmad (2013), perubahan tekstur pada buah disebabkan oleh perombakan pati menjadi gula sederhana berupa glukosa, fruktosa, dan sukrosa.

doi: http://dx.doi.org/10.23960/aec.v4.i1.2019.p01-12

Anal.Environ.Chem.Anal.Environ.Chem. 


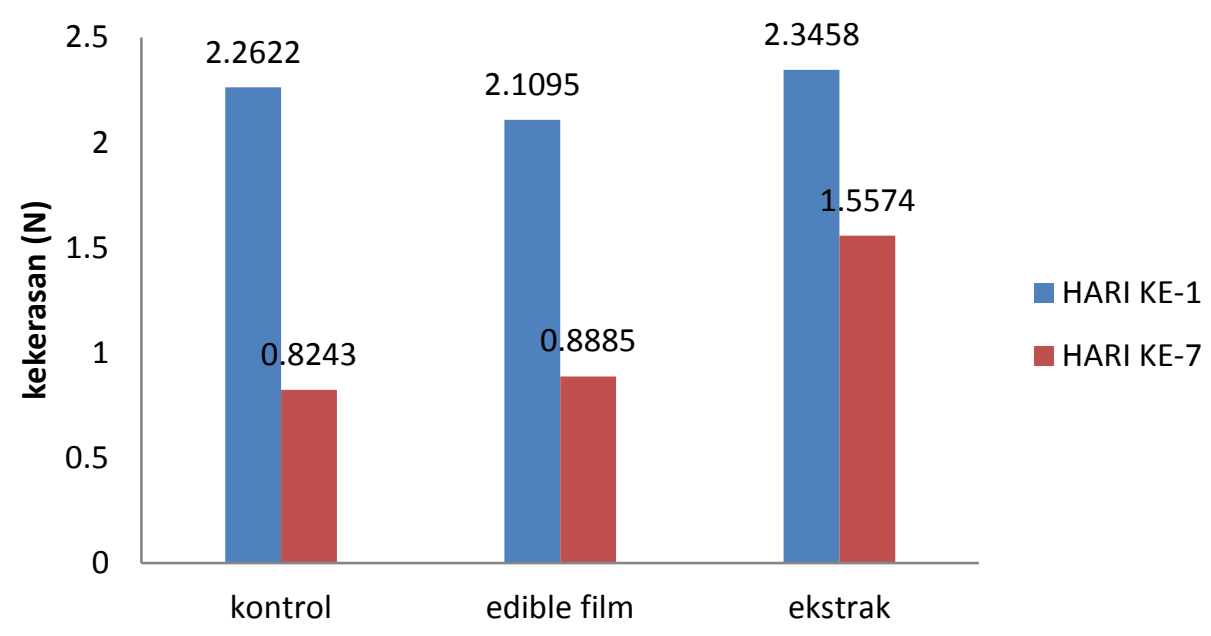

Gambar 6. Hasil Uji Tekstur Buah Tomat

Berdasarkan hasil tersebut menunjukkan lama penyimpanan mempengaruhi tekstur buah tomat. Tomat tanpa pelapisan edible film pada hari ke-1 nilai tekstur sebesar 2,26 menjadi 0,82 $\mathrm{N}$ pada hari ke-7 (Gambar 6). Hasil pengamatan tomat dengan pelapisan edible film tanpa penambahan menunjukkan perubahan pada hari ke-1 nilai tekstur sebesar 2,11 $\mathrm{N}$ kemudian di hari ke-7 menjadi 0,89 N. Sedangkan, tomat yang dilapisi edible film dengan penambahan ekstrak jahe pada hari ke-1 sebesar 2,35 $\mathrm{N}$ dan pada hari ke- 7 menjadi 1,56 $\mathrm{N}$.

Tomat yang dilapisi dengan edible film menunjukkan penurunan tingkat kekerasan yang tidak besar pada hari ke-7, jika dibandingkan dengan tomat tanpa pelapisan yang mengalami penurunan tingkat kekerasan yang cukup besar pada hari ke-7. Tomat yang dilapisi edible film dengan penambahan ekstrak jahe menunjukkan penurunan tingkat kekerasan yang lebih rendah dibandingkan dengan tomat yang dilapisi edible film tanpa penambahan. Pada tomat tanpa pelapisan terjadi proses metabolisme yang lebih cepat dibandingkan dengan tomat yang dilapisi edible film.

Hasil tersebut menunjukkan bahwa edible film dengan penambahan ekstrak jahe mampu menjaga tingkat kekerasan tomat atau menghambat proses pelunakan akibat terjadinya respirasi dan transpirasi yang terjadi pada buah tomat. Edible film akan menghambat oksigen yang akan masuk ke jaringan sehingga enzim-enzim yang terlibat dalam proses respirasi dan pelunakan jaringan menjadi kurang aktif (Rudito, 2005). Laju respirasi yang berjalan lambat dapat menunda kematangan tomat dan mengurangi degradasi tekstur selama penyimpanan (Ben-Yehoshua, 1987).

doi: http://dx.doi.org/10.23960/aec.v4.i1.2019.p01-12 
Kemampuan edible film untuk memperpanjang masa simpan berdasarkan tingkat kekerasan tekstur tomat dapat ditinjau dari persentase penurunan kekerasan tomat selama 7 hari. Persentase penurunan kekerasan tomat selama 7 hari yaitu 63\%. Pelapisan tomat dengan edible film tanpa ekstrak jahe mengalami penurunan tingkat kekerasan sebesar 63\% yaitu 7,5 hari, sedangkan tomat yang dilapisi edible film dengan penambahan ekstrak jahe akan mengalami penurunan tingkat kekerasan pada hari ke-12 masa simpan. Selisih antara tomat kontrol (tanpa pelapisan) tidak berbeda jauh dengan tomat pelapisan edible film tanpa penambahan ekstrak jahe, namun tomat dengan pelapisan edible film dengan penambahan ekstrak jahe menunjukkan perbedaan yang sangat signifikan. Hasil tersebut menunjukkan pengaruh nyata penambahan ekstrak jahe pada edible film dalam memperpanjang masa simpan.

\section{KESIMPULAN}

Berdasarkan penelitian yang telah dilakukan dapat disimpulkan bahwa Konsentrasi ekstrak jahe terbaik pada konsentrasi $0,75 \%$ untuk penambahan edible film pati ganyong-lidah buaya dengan besar kuat tarik 5,17 MPa, elongasi 9,74\%, dan WVTR 8,92 g/m².jam. Pelapisan edible film pati ganyong-lidah buaya dengan penambahan ekstrak jahe pada buah tomat menunjukkan pengaruh nyata. Penambahan ekstrak jahe ke dalam edible film mampu menjaga kualitas dan masa simpan buah tomat jika ditinjau berdasarkan 50\% penyusutan bobot dan 63\% kerusakan tekstur. Penyusutan 50\% bobot tomat yang dilapisi edible film dengan penambahan ekstrak jahe yaitu pada hari ke-65. Penurunan tingkat kekerasan tekstur sebesar 63\% pada tomat dengan pelapisan edible film dengan penambahan ekstrak jahe pada hari ke-12.

\section{UCAPAN TERIMA KASIH}

Terima kasih kepada Bapak Endaruji Sedyadi, S.Si., M.Sc dan Ibu Susy Yunita Prabawati, M.Si yang telah membantu dalam menyelesaikan penelitian ini.

\section{DAFTAR PUSTAKA}

Afriyah, Y., Widya, Dwi R.P ., dan Sudarma, Dita W. 2015. Penambahan Aloe Vera L. dengan Tepung Sukun (Artocarpuscommunis) dan Ganyong (Canna edulis Ker.) Terhadap Karakteristik Edible Film. Jurnal Pangan dan Agroindustri Vol. 3 No 4 p.1313-1324 
Blouis, M. S. 1958. Antioxidant Determinations by The USe of A Stable Free Radical. Juornal Nature 181: 1199-1200.

Embuscardo, M. E dan Huber, K.C. Edible Film and Coatings for Food Applications. Springer:New York,2009:32-33.

Estiningtyas, H., R. 2010. Aplikasi Edible Film Maizena Dengan Penambahan Ekstrak Jahe Sebagai Antioksidan Alami Pada Coating Sosis Sapi. (Skripsi). Surakarta. Universitas Sebelas Maret.

Krochta, J.M. 1992. Control Of Mass Transfer In Food With Edible Coating And Film. Technomic Publishing Co. Inc. Lancaster, USA.

Krochta, J.M., Baldwin E.A., Nisperos-Carriedo M.O.1994. Edible Coatings and Films to Improve Food Quality. USA : Technomic Publication, Co. Inc

Krochta, J. M and C. M., Johnson. 1997. Edible Film and Biodegradable Polymer Film Challenger and Opportunities. Food Tech, 51 (2):61-74

Kusumawati, D. H dan Putri, W. D. R. 2013. karakteristik Fisik dan Kimia Edible Film Pati Jagung yang Diinkoporasi dengan Perasan Temu Hitam. Jurnal Pangana dan Agroindustri Universitas Brawijaya Vol. 1 No. $1: 90-100$.

Lestari, R. B dan Yohana, S. K. D. 2008. Teknologi Produksi Biodegradable Film dari Aloe Vera dan Aplikasinya Sebagai Pengemas Ramah Lingkungan pada Buah Duku. Jurnal Penelitian Universitas Tanjungpura Vol. 10 No. 2.

Martin, J.T., Cerqueira, M. A., Boubon, A.I., Pinheiro, A.C., Souza, B. W. S. and Vicente, A.A.. 2012. Synergistic Effects Between Carrageenan and Locust Bean Gum on Physicochemical Properties of Edible Film Made There of. Food Hydrocolloids. 29:280-289.

Moluneux, P. 2004. The Use of The Stable Free Radical Diphenyl-Picryhydracyl (DPPH) for Estimating Antioxidant Activity. Journal Science of Technology 26(2):211-219.

Nwinuka, N., G. Ibeh dan G. Ekeke. 2005. Ptoximate Composition and levels of some toxicant in four Commonly Consumed Spices. J. Appl. Sci. Environ. Mgt. 9:150-155.

Pavlat, A.E and orts, W. 2009. Edible Films and Coatings: Why, What, and How. In Embuscado, E. M. and Huber K. C. (Eds). Edible film and Coatings for Food Applications, p.1-23. New York:Springer.

Robertson, L. G. 1992. Food Packaging Principles and practice. Marcel Dekker, New York

Rodriguez, M., Oses, J., Ziani, K. and Mate, J. I. 2006. Combined Effect Of Plasticizer And Surfactans On The Physical Properties Of Starch Based Edible Films. Journal of Food Research International, 39:840-846.

Saragih, Junedi; Assa, Jan; dan Langi, Tineke. 2015. Aktivitas Antioksidan Ekstrak Jahe Merah (Zingiber officinale var.rubrum) Menghambat Oksidasi Minyak Kacang Tanah (Arachis hypogaea L.) Jurnal Teknologi Pangan Fakultas Pertanian UNSRAT.

Sedyadi, E., Aini, S. K., Anggraini, D., Ekawati, D. P. 2016. Starch-Glycerol Based Edible Film and Effect of Rosella (Hibiscus Sabdariffa Linn) Extract and Surimi Dumbo Catfish (Clarias gariepinus) Addition on Its Mechanical Properties. Biology, Medicine, \& Natural Product Chemistry. 5(2): 3340

Zakaria, 2000. Pengaruh Konsumsi Jahe (Zingiber officinale Roscoe) Terhadap Kadar Malonaldehida dan Vitamin E Plasma Pada Mahasiswa Pesantren Ulil Albab Kedung Badan, Bogor. Buletin Teknologi dan Industri Pangan, Vol. XI, No. 1, T 2000. IPB. Bogor

doi: http://dx.doi.org/10.23960/aec.v4.i1.2019.p01-12

Anal.Environ.Chem.Anal.Environ.Chem. 